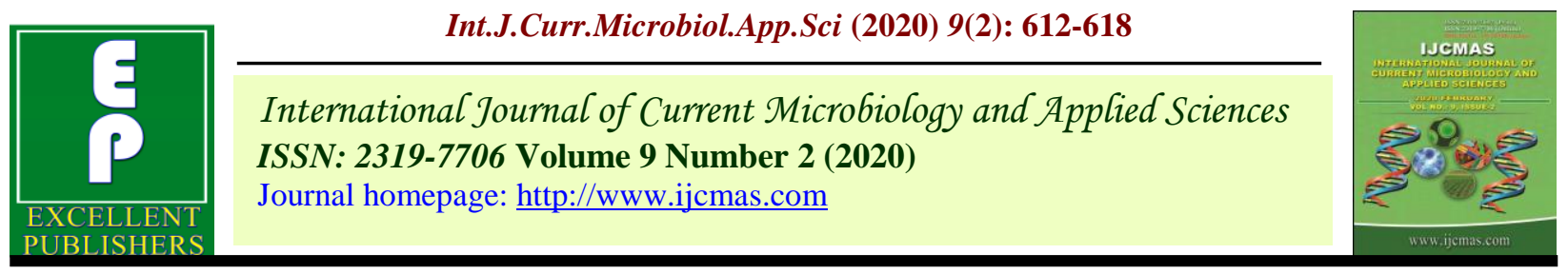

Original Research Article

https://doi.org/10.20546/ijcmas.2020.902.075

\title{
Effect of Different Nitrogen Levels and Varieties on Protein and Nitrogen Content in Grain and Nitrogen Uptake by Barley (Hordeum vulgare L.) in Sodic Soil
}

\author{
Shipra Yadav ${ }^{1 *}$, Rajesh Kumar ${ }^{2}$, Sanjay Singh Chauhan ${ }^{2}$, \\ Rahul Kumar ${ }^{1}$, and Mukesh Kumar ${ }^{1}$
}

${ }^{1}$ Department of Agronomy, Sardar Vallabhbhai Patel University of Agriculture \& Technology, Meerut, (UP) India

${ }^{2}$ Department of Agronomy, Narendra Deva University of Agriculture \& Technology, Kumarganj, Ayodhya, (UP) India

*Corresponding author

\section{Keywords}

Barley, Nitrogen levels, Protein content

Article Info

Accepted:

08 January 2020

Available Online:

10 February 2020

\section{A B S T R A C T}

A field experiment was conducted at Main Experimental Station of Narendra Deva University of Agriculture \& Technology, (Kumarganj), Ayodhya (U.P.) during Rabi season of 2016-17 to study the performance of barley varieties under various nitrogen levels in sodic soil. The trial was laid out in Split Plot Design. Nitrogen levels (60, 75 and $90 \mathrm{~kg} \mathrm{~N}^{-1}$ ) were kept in main-plots and varieties (RD-2907, RD-2552, NDB-1173 and RD-2794) in sub-plots with three replications on sodic soils having low organic carbon $\left(0.38 \mathrm{~g} \mathrm{~kg}^{-1}\right)$, available nitrogen $\left(185.0 \mathrm{~kg} \mathrm{ha}^{-1}\right)$, phosphorus (15.25 kg ha $\mathrm{kg}^{-1}$ and potassium $\left(265 \mathrm{~kg} \mathrm{ha}^{-1}\right)$. Data manifested to nitrogen content and uptake of barley grain and straw as influenced by nitrogen levels and varieties. Maximum nitrogen content (1.68) in grain, (0.54\%) in straw determined with application of $90 \mathrm{~kg} \mathrm{~N} \mathrm{ha}^{-1}$ which was at par with the dose of 75 $\mathrm{kg} \mathrm{N} \mathrm{ha}{ }^{-1}$ and lowest with $60 \mathrm{~kg} \mathrm{~N} \mathrm{ha}^{-1}$. The Maximum nitrogen uptake in grain $\left(47.13 \mathrm{~kg} \mathrm{ha}^{-1}\right)$ and straw $\left(24.80 \mathrm{~kg} \mathrm{ha}^{-1}\right)$ was recorded under the supply of $90 \mathrm{~kg} \mathrm{~N}$ $\mathrm{ha}^{-1}$ which was significantly higher than 75 and $60 \mathrm{~kg} \mathrm{~N}^{-1}$. There was no significant difference in term of nitrogen content in grain due to different varieties of barley crop. Maximum nitrogen content (0.55) in straw was recorded in variety RD-2907 which was at par with RD-2552 (0.54\%) and significantly maximum over rest of the varieties. Among the varieties of barley, maximum nitrogen uptake by grain and straw (48.31 and $25.25 \mathrm{~kg} \mathrm{ha}^{-1}$, respectively) was recorded in variety (RD-2907) which was at par with (24.52) RD-2552 and significantly superior to RD-2794 and NDB-1173. Nitrogen and protein content in grain increased with increasing levels of nitrogen. Maximum nitrogen content (1.68\%) and protein content $(10.54 \%)$ in grain was observed with $90 \mathrm{~kg} \mathrm{~N} \mathrm{ha}^{-1}$. The varieties had no significant effect on nitrogen and protein content in grain. 


\section{Introduction}

Barley is the fourth most important cereal crop in the world after rice, wheat and maize. Although generally a temperate crop, barley is also grown in many tropical countries, typically by poor farmers in hostile, dry, cool environments. In India, barley crop was grown over an area of seven lac hectare with a production of $1700 \mathrm{mt}$ and productivity of $22.50 \mathrm{q} \mathrm{ha}^{-1}$ during 2016-2017 (Anonymous, 2017). Uttar Pradesh is one of the most important barley growing states of India. This crop has industrial demand due to use of malt. It is used in different forms such as bread, porridge, soup and roasted grain and for preparing alcoholic and non-alcoholic drinks.

The barley crop has wider adoptability and less water requirement, it is more tolerant to salinity and other stress conditions. Therefore, it is of great significance in areas where successful wheat crop cannot be grown due to unsuitable soil and insufficient irrigation. Nitrogen is a key factor in achieving an optimum yield in cereals and in their growing period requires lot amount of absorbed nitrogen. Proper dose of nitrogen increased leaf area, tillers formation, leaf area index and leaf area duration and which lead to greater production of dry matter and grain yield. Salinity stress affect plants nutrient uptake and metabolic activity in plant. However salinity and alkalinity effects magnitude is depending upon plant species and level of salinity. Salinity and alkalinity stress adversely affects all stage of growth and development such as germination growth and vigour of seeding, vegetative growth flowering and grain filling and ultimately causing diminished economic yield and also quality of products. The rate of uptake and partition of $\mathrm{N}$ is largely determined by supply and demand during various stages of plant growth. Meena et al., (2012) reported that Nitrogen content in grain and straw and nitrogen uptake by grain and straw increased successively with each level of $\mathrm{N}$ and it was increased from 30 to $90 \mathrm{~kg} \mathrm{~N} / \mathrm{ha}$.

\section{Materials and Methods}

A field experiment was conducted at Main Experimental Station of Narendra Deva University of Agriculture \& Technology, (Kumarganj), Ayodhya (U.P.) during Rabi season of 2016-17 to study the performance of barley varieties under various nitrogen levels in sodic soil. The trial was laid out in Split Plot Design. Nitrogen levels (60, 75 and $90 \mathrm{~kg} \mathrm{~N}$ ha-1) were kept in main-plots and varieties (RD-2907, RD-2552, NDB-1173 and RD-2794) in sub-plots with three replications on sodic soils having low organic carbon (0.38 g kg-1), available nitrogen $(185.0 \mathrm{~kg}$ ha1), phosphorus (15.25 kg ha-1) and potassium (265 kg ha-1).

The experimental site falls under sub-tropical zone in Indo-gangatic plains and lies between 26047' North latitude, 82012' east longitudes, at an altitude of about 113.0 meter from mean sea level and is subjected to extremes of weather conditions. The total rainfall during course of experimentation was $17.5 \mathrm{~mm}$. During the crop season, the lowest temperature (4.90C) was recorded in the month of January and the maximum (39.00C) in the month of April.

The highest mean relative humidity $(88.2 \%)$ was recorded in the month of January (fig. 1). The trial was laid out in Split Plot Design. Nitrogen levels (60, 75 and $90 \mathrm{~kg} \mathrm{~N} \mathrm{ha}^{-1}$ ) were kept in main-plots and varieties (RD2907, RD-2552, NDB-1173 and RD-2794) in sub-plots with three replications on sodic soils having high $\mathrm{pH} 8.8$, low EC 0.37 , organic carbon $0.38 \mathrm{~g} \mathrm{~kg}^{-1}$, available nitrogen 185.0 $\mathrm{kg} \mathrm{ha}{ }^{-1}$, phosphorus $15.25 \mathrm{~kg} \mathrm{ha}^{-1}$ and potassium $265 \mathrm{~kg}$ ha . 


\section{Results and Discussion}

\section{Yield}

Different nitrogen levels and varieties had influence on grain yield. The yield was recorded significantly higher under $90 \mathrm{~kg} \mathrm{~N}$ $\mathrm{ha}^{-1}$ as compared to other treatments. This might be due to adequate nitrogen availability which contributed to increase dry matter accumulation. Productivity of a crop is collectively determined by vigour of the vegetative growth, development as well as yield attributes which is the result of better translocation of photosynthates from source (leaves and stem) to sink (grains). Better vegetative growth coupled with high yield attributes resulted into higher grain yield at 90 $\mathrm{kg} \mathrm{N} \mathrm{ha}{ }^{-1}$. Reduced nitrogen supply as in case of rest of the treatment, recorded lowest yield due to both poor growth and yield attributes. Similar finding were reported by Mal et al., (2014).

The grain yield of barley were significantly influenced by varieties. Highest yield was obtained under RD-2907 was at par with RD2552 and significantly higher than other varieties. The increase in grain yield under this variety was mainly due to improvement in yield attributes and growth of crop which might be due to the genetic characteristics of the variety. The grain yield as the result of growth and development through efficient assimilation and utilization of available nitrogen by the growing plants during the entire grand growth period. Growth in vegetative phase and development in reproductive phase determines the yield. Similar finding was reported by Ram and Dhaliwal (2012). Straw yield was influenced significantly by levels of nitrogen and different varieties. Maximum straw yield was recorded at $90 \mathrm{~kg} \mathrm{~N} \mathrm{ha-}{ }^{1}$ which was significantly higher than $75 \& 60 \mathrm{~kg} \mathrm{~N} \mathrm{ha}^{-1}$. This may be probably due to higher density of tiller and increased rate of dry matter production. Similar findings were reported by Rashmi (2012). Straw yield was noted higher under RD-2907 which was mainly due to more dry matter accumulation per unit area as a result of better performance of vegetative growth caused due to efficient assimilation and absorption of nitrogen from the soil during entire period of growth. Similar finding was reported by Sharma (2007). Harvest index of barley was not affected significantly due to nitrogen levels and different varieties. However, the performance was better at $90 \mathrm{~kg} \mathrm{~N} \mathrm{ha}^{-1}$ and RD- 2907, it might be due to more grain yield.

\section{Nitrogen content $(\%)$ in grain and straw}

The nitrogen content in grain increased with increasing rate of nitrogen. Maximum nitrogen content (1.68) in grain determined with applied $90 \mathrm{~kg} \mathrm{~N} \mathrm{ha}^{-1}$ which was at par with (1.65) the supply of $75 \mathrm{~kg} \mathrm{~N} \mathrm{ha}^{-1}$ and significantly superior to (1.62) $60 \mathrm{~kg} \mathrm{~N} \mathrm{ha}^{-1}$. No significant different was noticed on nitrogen content in grain due to different varieties of barley crop. Data revealed that the nitrogen content in straw increased with increasing rates of nitrogen levels.

Maximum nitrogen content $(0.54 \%)$ was recorded with $90 \mathrm{~kg} \mathrm{~N} \mathrm{ha}^{-1}$ and at par with 75 $\mathrm{kg} \mathrm{N} \mathrm{ha}{ }^{-1}(0.53)$ which was significantly higher over the application of $60 \mathrm{~kg} \mathrm{~N} \mathrm{ha}^{-1}$. Among varieties, maximum nitrogen content $(0.55)$ in straw was recorded in variety RD2907 which was at par with RD-2552 $(0.54 \%)$ and significantly maximum over rest of the varieties. Nitrogen content increased in grain with increasing nitrogen levels. Villers et al., (1988) also reported that nitrogen application increased total nitrogen, free amino nitrogen and alfa and beta amylase activities in barley grain. Similar findings were reported by Paramjit et al., (2001) and Singh and Singh (1991). 
Nitrogen uptake by grain and straw (kg ha 1)

Nitrogen uptake by grain as influenced by different nitrogen levels and varieties of barley crop. It is clear from the data that nitrogen uptake by grain increased significantly with the enhanced the dose of $\mathrm{N}$ levels. It was recorded maximum $(47.13 \mathrm{~kg}$ $\mathrm{ha}^{-1}$ ) under the application of $90 \mathrm{~kg} \mathrm{~N} \mathrm{ha}^{-1}$ which was significantly higher than $75 \mathrm{~kg}$ $\left(42.96 \mathrm{~kg} \mathrm{ha}^{-1}\right)$ and $60 \mathrm{~kg} \mathrm{~N} \mathrm{ha}^{-1}(36.61 \mathrm{~kg}$ $\left.\mathrm{ha}^{-1}\right)$. Among varieties maximum nitrogen uptake (48.31 kg ha ${ }^{-1}$ ) by the grain was recorded in RD-2907, which was at par with the variety of RD-2552 (46.32) and significantly superior over the varieties of RD-2794 and NDB-1173. The nitrogen levels and varieties had significant effect on nitrogen uptake straw. The data revealed that nitrogen uptake by straw increased significantly with the increase in $\mathrm{N}$ levels. Maximum nitrogen uptake by straw was recorded $\left(24.80 \mathrm{~kg} \mathrm{ha}^{-1}\right)$ under the supply of
$90 \mathrm{~kg} \mathrm{~N} \mathrm{ha}{ }^{-1}$ which was significantly higher than 75 and $60 \mathrm{~kg} \mathrm{~N} \mathrm{ha}^{-1}$.Among the varieties of barley, maximum nitrogen uptake (25.25 $\mathrm{kg} \mathrm{ha}^{-1}$ ) by straw was recorded in variety (RD-2907) which was at par with (24.52) RD2552 and significantly superior to RD-2794 and NDB-1173. This might be due to better root establishment which resulted in better translocation of absorbed nutrient from soil and its transport to the plant and seed which may cause higher plant growth and grains and straw yields and ultimately increased the uptake of nitrogen. The lowest uptake of nitrogen recorded in minimum dose of nitrogen application was due to poor root growth, nitrogen mobilization, grain and straw yields. Similar results were reported by Meena et al., (2012). Plant under RD-2907 variety trapped adequate amount of nitrogen from the soil through effective root zone leading to increased nitrogen content in grain and straw and recorded maximum yield. Maximum uptake in variety RD-2552 might be due to higher nitrogen content and yield.

Table.1 Nitrogen uptake by grain and straw and total nitrogen uptake as influenced by different nitrogen levels and varieties of barley crop

\begin{tabular}{|c|c|c|c|}
\hline Treatments & $\begin{array}{l}\text { Nitrogen uptake by } \\
\text { grain }\left(\mathrm{kg} \mathrm{ha}^{-1}\right)\end{array}$ & $\begin{array}{l}\text { Nitrogen uptake } \\
\text { by straw (kg ha') }\end{array}$ & $\begin{array}{c}\text { Total nitrogen } \\
\text { uptake }\left(\mathrm{kg} \mathrm{ha}^{-1}\right)\end{array}$ \\
\hline \multicolumn{4}{|l|}{ Nitrogen levels $\left(\mathrm{kg} \mathrm{ha}^{-1}\right)$} \\
\hline 60 & 36.66 & 18.77 & 55.43 \\
\hline 75 & 42.96 & 22.67 & 65.64 \\
\hline 90 & 47.13 & 24.80 & 71.94 \\
\hline SEm \pm & 0.43 & 0.26 & 0.65 \\
\hline $\mathrm{CD}(\mathrm{P}=\mathbf{0 . 0 5})$ & 1.76 & 1.05 & 2.64 \\
\hline \multicolumn{4}{|l|}{ (B) Varieties } \\
\hline RD-2907 & 48.31 & 25.25 & 73.57 \\
\hline RD-2552 & 46.32 & 24.52 & 70.85 \\
\hline NDB-1173 & 35.21 & 18.16 & 53.38 \\
\hline RD-2794 & 39.15 & 20.39 & 59.55 \\
\hline SEm \pm & 1.49 & 0.94 & 2.42 \\
\hline $\mathrm{CD}(\mathrm{P}=0.05)$ & 4.48 & 2.84 & 7.25 \\
\hline
\end{tabular}


Table.2 Nitrogen content in grain and straw as well as protein content in grain as influenced by different nitrogen levels and varieties of barley crop

\begin{tabular}{|l|c|c|c|}
\hline \multicolumn{1}{|c|}{ Treatments } & $\begin{array}{c}\text { N content in grain } \\
(\mathbf{\%})\end{array}$ & $\begin{array}{c}\text { N content in straw } \\
(\mathbf{\%})\end{array}$ & $\begin{array}{c}\text { Protein content in } \\
\text { grain }(\mathbf{\%})\end{array}$ \\
\hline Nitrogen levels $\left(\mathbf{k g ~ h a}^{-\mathbf{1}}\right)$ & 1.62 & 0.52 & 10.14 \\
\hline $\mathbf{6 0}$ & 1.65 & 0.53 & 10.33 \\
\hline $\mathbf{7 5}$ & 1.68 & 0.54 & 10.54 \\
\hline $\mathbf{9 0}$ & 0.01 & 0.004 & 0.07 \\
\hline SEm \pm & 0.04 & 0.01 & 0.28 \\
\hline CD $(\mathbf{P = 0 . 0 5 )}$ & & & 10.62 \\
\hline (B) Varieties & 1.70 & 0.55 & 10.37 \\
\hline RD-2907 & 1.66 & 0.54 & 10.31 \\
\hline RD-2552 & 1.65 & 0.52 & 10.06 \\
\hline NDB-1173 & 1.60 & 0.51 & 0.13 \\
\hline RD-2794 & 0.02 & 0.008 & NS \\
\hline SEm \pm & NS & 0.02 & \\
\hline CD $(\mathbf{P = 0 . 0 5 )}$ & & & \\
\hline
\end{tabular}

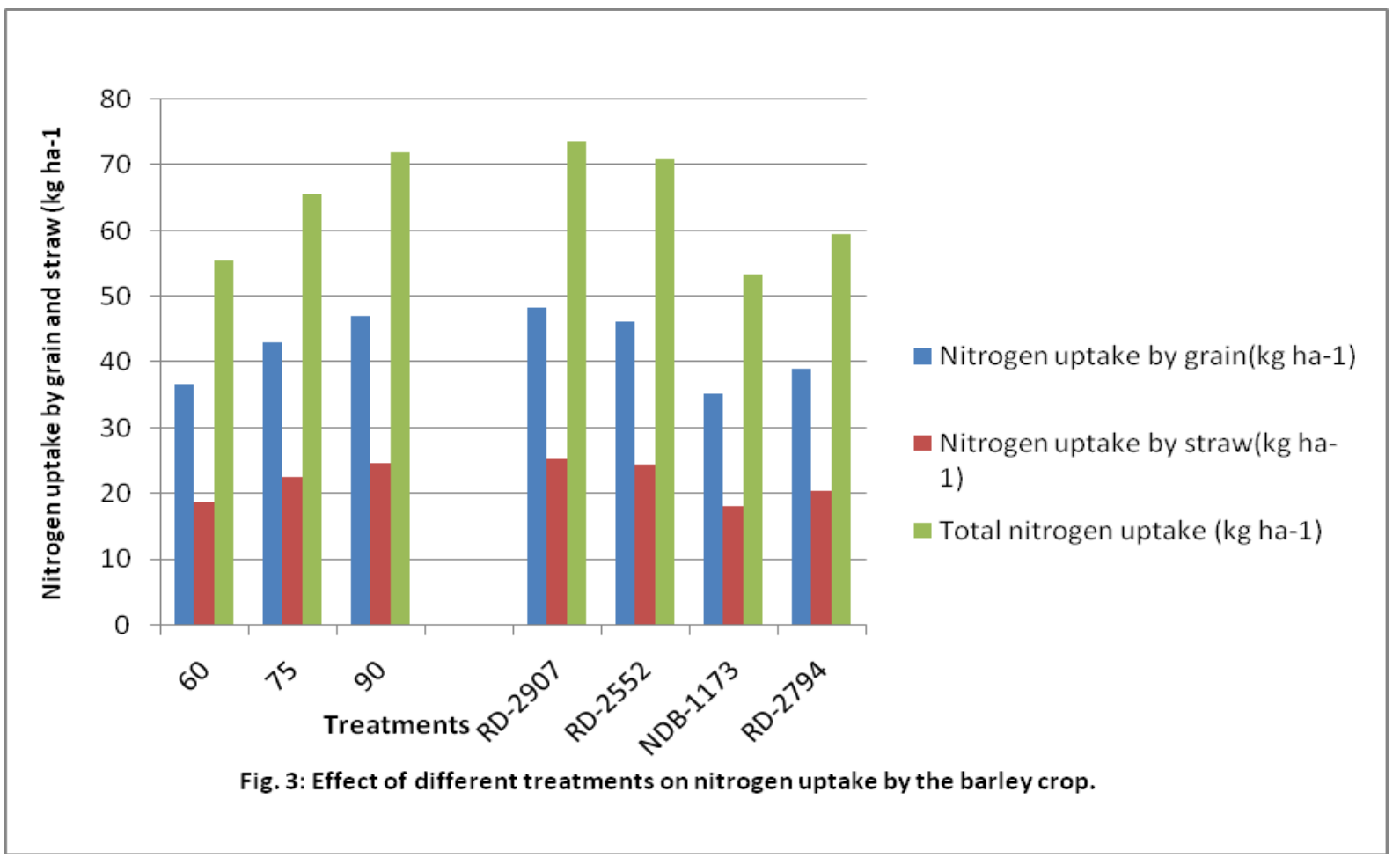




\section{Protein content in grain (\%)}

Data pertaining to protein content in grain as influenced by different nitrogen levels and varieties of barley crop. Protein content in grain increased with increasing rates of nitrogen [Table 2]. Maximum protein content $(10.54 \%)$ was recorded with the application of $90 \mathrm{~kg} \mathrm{~N} \mathrm{ha}{ }^{-1}$ which was at par with $75 \mathrm{~kg} \mathrm{~N}$ $\mathrm{ha}^{-1}$ and significantly higher than $60 \mathrm{~kg} \mathrm{~N}$ ha ${ }^{1}$.The varieties had non significant effect on the protein content in grain. Protein content of grain increased due to increase in nitrogen content of grain. This was due to well established fact that nitrogen in the structural constituent of protein structure in living cells. Thus the maximum protein content was recorded at $90 \mathrm{~kg} \mathrm{~N}^{-1}$. Similar results were observed by Paramjit et al., (2001).

\section{Economics}

The highest gross return of Rs. $71666 \mathrm{ha}^{-1}$ was obtained from $90 \mathrm{~kg} \mathrm{~N}^{-1}$ with variety RD-2907 followed by Rs. $70918 \mathrm{ha}^{-1} 90 \mathrm{~kg} \mathrm{~N}$ $\mathrm{ha}^{-1}$ with RD-2552. The lowest gross return (Rs. $50399 \mathrm{ha}^{-1}$ ) was obtained under $60 \mathrm{~kg} \mathrm{~N}$ $\mathrm{ha}^{-1}$ with variety NDB-1173 due to lowest yield. Maximum cost of cultivation (Rs.26155 $\mathrm{ha}^{-1}$ ) was recorded under dose of $90 \mathrm{~kg} \mathrm{~N} \mathrm{ha}^{-1}$ followed by (Rs. $25928 \mathrm{ha}^{-1}$ ) in $75 \mathrm{~kg} \mathrm{~N} \mathrm{ha}^{-1}$ and the lowest was with $60 \mathrm{~kg} \mathrm{~N}^{-1}$. Highest net return of Rs. $45511 \mathrm{ha}^{-1}$ was obtained from $90 \mathrm{~kg} \mathrm{~N} \mathrm{ha}{ }^{-1}$ with variety RD-2907 followed by Rs. $44763 \mathrm{ha}^{-1} 90 \mathrm{~kg} \mathrm{~N}^{-1}$ with RD-2552. The lowest net return of Rs. $24699 \mathrm{ha}^{-1}$ was recorded in $60 \mathrm{~kg} \mathrm{~N}^{-1}$ due to lowest gross return. Higher benefit-cost ratio (1.74) was obtained under the treatment combination of $90 \mathrm{~kg} \mathrm{~N} \mathrm{ha}{ }^{-1}$ with RD-2907 followed by (1.71) in $90 \mathrm{~kg} \mathrm{~N}^{-1}$ with RD-2552. The lowest benefit-cost ratio (0.96) was observed with the treatment $60 \mathrm{~kg} \mathrm{~N}^{-1}$, NDB-1173. The similar finding reported by Puniya et al., (2015).
As per the results of experiment presented and discussed in the paper, it can be concluded that the application of $90 \mathrm{~kg} \mathrm{~N} \mathrm{ha}^{-1}$ was the most suitable option for production of barley under sodic soil condition. Among the varieties, RD-2907 with $90 \mathrm{~kg} \mathrm{~N} h a^{-1}$ resulted in highest grain yield, protein and nitrogen content in grain and maximum nitrogen uptake. This combination was also found remunerative, which gave highest net return $\left(45511 \mathrm{ha}^{-1}\right)$ and B:C ratio (1.74).

\section{References}

Anonymous 2017. Agriculture statistics at a glance, Department of Agriculture and Co-operation, Ministry of Agriculture, Government of India, New Delhi.

Mal, T. Phogat, S.B., Kumar, S. and Singh, B. 2014. Effect of nitrogen on yield and quality of barley (Hordeum vulgare) genotypes. India J. Agron. 59 (1): 171-174.

Meena, L.R., Mann, J.S. and Meena, S.L. 2012. Effect of levels and mode of nitrogen application on dual purpose barley (Hordeum vulgare) under semiarid condition. Indian. J. Agron. 57(2): 168-170.

Paramjeet, Singh, V.P and Roy, D.K. 2001. Effect of different levels of nitrogen and irrigation on growth, yield and quality of malt barley (Hordeum vulgare L.). Res. crops. 2(2): 120-122.

Puniya, M.M., Yadav, S.S. and Shivran, A.C. 2015. Productivity, profitability and nitrogen-use efficiency of barley (Hordeum vulgare) as influenced by weed management and nitrogen fertilization under hot semi-arid ecologies of Rajasthan. Indian Journal of Agronomy 60(4): 564-569.

Rahimi, A. (2012). Effect of planting date and nitrogen on yield and yield components of dry land barley (Hordeum vulgare L.) grown in 
Boyerahmad Region of Iran. Research on Crops. 13(3):840-845.

Ram, H. and Dhaliwal, S.S. 2012. Effect of varieties and integrated nutrient management techniques on growth, productivity, quality and economics of barley (Hordeum vulgare L.). International Journal of Agricultural Science 8(1): 91-97.

Sharma, N.K. 2007. Effect of sowing time and cutting management on fodder yield of barley. Range Management \& Agroforestry. 28: 334-335.

Singh, J.P and Singh, V. 1991. Response of hulled and hull-less barley to varying levels of nitrogen and phosphorus. Indian J. Agron. 36: 104-107.

Villers, O.T.D.E.; Morre, P.L.J and Laubscger, E.W. 1988. Effect of time and rate of $\mathrm{N}$ application on the malting quality of barley. South Africa J. Plant and Soil. 5(3): 134-136.

\section{How to cite this article:}

Shipra Yadav, Rajesh Kumar, Sanjay Singh Chauhan, Rahul Kumar and Mukesh Kumar. 2020. Effect of Different Nitrogen Levels and Varieties on Protein and Nitrogen Content in Grain and Nitrogen Uptake by Barley (Hordeum vulgare L.) in Sodic Soil. Int.J.Curr.Microbiol.App.Sci. 9(02): 612-618. doi: https://doi.org/10.20546/ijcmas.2020.902.075 